\title{
PENERAPAN MODEL PEMBELAJARAN NHT UNTUK MENINGKATKAN HASIL BELAJAR IPA SISWA KELAS III
}

\author{
N. M. Juliartini ${ }^{1}$, N. W. Arini ${ }^{2}$ \\ 1,2 Program SKGJ Badung, Jurusan Pendidikan Guru Sekolah Dasar \\ Fakultas IImu Pendidikan, Universitas Pendidikan Ganesha \\ Singaraja, Indonesia
}

e-mail: nimadejuliartini89@gmail.com, wayanarini@yahoo.co.id

\begin{abstract}
Abstrak
Penelitian ini bertujuan untuk mengetahui peningkatan hasil belajar IPA setelah penerapan model pembelajaran NHT pada siswa kelas III Sekolah Dasar No. 2 Abianbase tahun Pelajaran 2016/2017. Jenis penelitian ini adalah Penelitian Tindakan Kelas dengan subjek seluruh siswa kelas III Sekolah Dasar No. 2 Abianbase tahun pelajaran 2016/2017 berjumlah 31 orang siswa. Data hasil belajar yang dikumpulkan dengan tes hasil belajar IPA. Selanjutnya data tersebut dianalisis dengan metode analisis deskriptif kuantitatif. Hasil penelitian menunjukkan bahwa penerapan Model Pembelajaran NHT dapat meningkatkan Hasil belajar pada pembelajaran IPA siswa kelas III di SD No. 2 Abianbase, Kabupaten Badung. Hal ini dapat diketahui dari hasil yang diperoleh pada siklus I, ratarata hasil belajar siswa pada siklus I hanya mencapai 72,74 dengan persentase sebesar $72,74 \%$ termasuk kategori hasil belajar sedang. Setelah diadakan perbaikkan pada siklus II, diperoleh hasil belajar mencapai 81,93 dengan persentase 81,93\% termasuk kategori tinggi. Dengan demikian dapat disimpulkan bahwa penerapan model pembelajaran NHT pada mata pelajaran IPA dapat meningkat hasil belajar siswa kelas III SD No. 2 Abianbase, Kabupaten Badung, Tahun Pelajaran 2016/2017.
\end{abstract}

Kata kunci : NHT, Hasil Belajar

\begin{abstract}
This study aims to determine the learning outcome IPA after NHT learning model application in class III Elementary School No. 2 Abianbase year 2016/2017. This research is a classroom action research with the subject of the entire third grade students of Elementary School No. 2 Abianbase school year 2016/2017 amounted to 31 students. Learning outcomes data collected by the test results to learn science. Furthermore, the data was analyzed by quantitative descriptive analysis. The results showed that the application of NHT learning model can improve learning outcomes in science teaching thirdgrade students in elementary school No. 2 Abianbase, Badung regency. It can be seen from the results obtained in the first cycle, the average student learning outcomes in the first cycle only reached 72.74 with a percentage of $72.74 \%$ are moderate learning outcomes. Having held any improvement in the second cycle, the result of learning reached 81.93 with the percentage of $81.93 \%$ were high. It can be concluded that the application of the learning model of NHT in science subjects can increase student learning outcomes Class III SD No. 2 Abianbase, Badung, in the academic year 2016/2017.
\end{abstract}

Key word : NHT, Learning outcome

\section{PENDAHULUAN}

Proses pembelajaran yang diharapkan terjadi di tiap-tiap sekolah adalah suatu proses yang dapat mengembangkan potensi-potensi siswa secara menyeluruh dan terpadu. Karena itu dalam proses pembelajaran, guru tidak hanya dituntut menyampaikan materi pembelajaran akan tetapi mengaktualisasi peran strategisnya dalam upaya membentuk watak siswa melalui pengembangan kepribadian dan nilai-nilai yang berlaku. Dalam proses pembelajaran akan diajarkan materimateri yang ada pada masing-masing mata pelajaran salah satunya mata pelajaran IPA. Di sekolah dasar IPA dipelajari sejak kelas $1 \mathrm{SD}$ dengan mengenal segala sesuatu yang ada disekitar siswa. IPA sangat perlu diajarkan agar kehidupan manusia 
semakin maju dengan beragam pengetahuan dan teknologi yang diciptakan. Siswa yang memiliki pengetahuan pada suatu mata pelajaran dapat dilihat dari hasil belajar yang diperoleh. Begitu pula dengan mata pelajaran IPA dapat dilihat dari hasil belajar IPA siswa tersebut. Namun pada pelaksanaan pembelajaran IPA masih banyak siswa yang belum memperoleh hasil belajar IPA yang memuaskan.

Berdasarkan pengalaman mengajar di kelas III SD dalam proses pembelajaran IPA lebih banyak menggunakan metode ceramah yang proses pembelajaran masih berpusat pada guru. Proses pembelajaran guru lebih banyak memberikan informasi, siswa sering bermain, mengobrol dengan teman pada saat guru menjelaskan materi pembelajaran. Jumlah siswa dalam satu kelas terlalu banyak, siswa kurang aktif dalam menjawab pertanyaan yang diberikan oleh guru. Konsep materi pelajaran belum dikuasai siswa. Dengan proses pembelajaran yang seperti itu mengakibatkan siswa kurang aktif, cenderung pasif dalam mengikuti proses pembelajaran, siswa kurang fokus dalam memahami materi pembelajaran yang diberikan. Tidak ada aktivitas siswa yang sangat berperan dalam pembelajaran.

$\mathrm{Hal}$ ini diperkuat dengan hasil ulangan harian yaitu dengan rata-rata hasil ulangan harian mata pelajaran IPA 60,70 yang belum memenuhi KKM yang ditentukan yaitu 75 , hal ini dapat dilihat dari sebanyak 22 siswa dari 31 siswa berada di bawah KKM. Untuk mengatasi permasalahan tersebut, maka perlu dicarikan solusi agar pembelajaran IPA yang dilaksanakan menjadi lebih bermakna sehingga dapat memberikan pengaruh positif terhadap peningkatan hasil belajar IPA siswa di SD No. 2 Abianbase. Salah satu solusi untuk mengatasi permasalahan tersebut, yaitu dengan menerapkan salah satu model pembelajaran yang mampu memberikan pengalaman belajar yang melibatkan proses mental dan fisik melalui interaksi antara siswa dengan guru, siswa dengan siswa, lingkungan, dan sumber belajar lainnya dalam situasi yang menyenangkan bagi siswa.

Maka dari itu, tampak bahwa hasil belajar IPA masih sangat rendah. Oleh karena itu, diupayakan jalan keluar untuk mengatasi masalah tersebut dengan menerapkan model pembelajaran Number Head Together (NHT). Kurniasih \& Sani, (2015) menyatakan bahwa pembelajaran kooperatif tipe NHT ini lebih menekankan pada struktur khusus yang dirancang untuk mempengaruhi pola interaksi siswa agar memiliki tujuan untuk meningkatkan penguasaan akademik. Model pembelajaran Number Head Together (NHT) memiliki beberapa keunggulan yaitu: 1) model ini menuntut siswa harus aktif semua, 2) dengan model pembelajaran ini juga, siswa dituntut untuk melakukan diskusi dengan sungguh-sungguh, 3) siswa yang pandai dapat mengajari siswa yang kurang pandai.

Berdasarkan uraian yang telah dipaparkan di atas, maka dalam penelitian ini akan dilakukan Penerapan Model Pembelajaran Number Head Together (NHT) Untuk Meningkatkan Hasil Belajar IPA Siswa Kelas III SD No. 2 Abianbase Kabupaten Badung Tahun Ajaran 2016/2017.

Berdasarkan latar belakang diatas, maka dapat dirumuskan masalahnya sebagai berikut, "Apakah dengan menerapan model pembelajaran Number Head Together (NHT) dapat meningkatkan hasil belajar IPA siswa kelas III SD No. 2 Abianbase Kabupaten Badung Tahun Ajaran 2016/2017"? Berdasarkan rumusan masalah penelitian ini, maka tujuan penelitian ini adalah "untuk mengetahui peningkatkan hasil belajar IPA siswa kelas III SD No. 2 Abianbase Kabupaten Badung Tahun Ajaran 2016/2017 dengan penerapan model pembelajaran Number Head Together (NHT)".

Wahaya (dalam Trianto, 2010) mengatakan bahwa, "IPA adalah suatu kumpulan pengetahuan tersusun secara sistematik dan dalam penggunaannya secara umum terbatas pada gejalagejala alam. Perkembangannya tidak 
hanya ditandai oleh adanya kumpulan fakta, tetapi oleh adanya metode ilmiah dan sikap ilmiah". Trianto, (2011) menyimpulkan bahwa IPA adalah suatu kumpulan teori yang sistematis, penerapannya secara umum terbatas pada gejala-gejala alam, lahir dan berkembang melalui metode ilmiah seperti observasi dan eksperimen serta menuntut sikap ilmiah seperti rasa ingin tahu, terbuka, jujur dan sebagainya.

Dari secara kelompok yang berpusat pada siswa. Melalui kegiatan kelompok semua siswa terlibat dalam mempelajari dan menyelesaikan tugas yang dibebankan. Model pembelajaran kooperatif merupakan teknik-teknik kelas praktis yang dapat digunakan guru setiap hari untuk membantu siswa belajar setiap mata pelajaran, mulai dari keterampilan dasar sampai memecahkan masalah yang kompleks (Nur, 2005; Suprijono, 2009; Agustin, dkk, 2013). Maka dengan pembelajaran kooperatif siswa diharapkan mampu menciptakan situasi dimana Maka dari itu untuk mendukung pemecahan masalah digunakan model pembelajaran kooperatif tipe NHT. Menurut Trianto (2007) Model pembelajaran NHT merupakan suatu pendekatan untuk melibatkan banyak siswa dalam memperoleh materi yang tercakup dalam suatu pelajaran dan mengecek pemahaman mereka terhadap isi pelajaran.

NHT merupakan salah satu jenis model pembelajaran kooperatif yang dikembangkan oleh Spencer Kagan (1992) untuk melibatkan lebih banyak siswa dalam menelaah materi yang tercakup dalam suatu pelajaran dan mengecek pemahaman mereka terhadap isi pelajaran (Trianto, 2007; Kusumaningtyas, dkk, 2014; Miaz, 2015; Puspa, dkk, 2015, Kurniasih \& Sani, 2015). NHT adalah suatu metode belajar yang setiap anak diberi nomor kemudian dibuat satu kelompok lalu guru memanggil secara acak nomor dari siswa tersebut. Shoimin, (2014) menyatakan bahwa model pembelajaran NHT adalah suatu model pembelajaran berkelompok yang setiap anggota kelompoknya bertanggung jawab atas tugas kelompoknya, sehingga tidak ada pemisahan antar siswa yang satu dengan yang lainnya. Model pembelajaran ini harus dilaksanakan dengan memberikan penomoran sehingga setiap siswa dalam timnya mempunyai nomor yang berbeda-beda, sesuai dengan jumlah siswa di dalam kelompok (Kurniasih \& Sani, 2015).

Dari beberapa uraian di atas dapat disimpulkan bahwa NHT adalah model pembelajaran yang dapat memberikan rasa tanggung jawab kepada anak untuk menyelesaikan tugas dan melatih perkembangan otak anak untuk mencari tahu sendiri apa yang telah ditugaskan. Langkah-langkah tersebut kemudian dikembangkan oleh Kurniasih \& Sani, (2015) menjadi enam langkah sebagai berikut. Langkah 1. Persiapan Dalam tahapan ini guru mempersiapkan rancangan pelajaran yang sesuai dengan model pembelajaran kooperatif tipe NHT. Langkah 2. Membagi kelompok Kelompok yang dibentuk, harus sesuai dengan model pembelajaran kooperatif tipe $\mathrm{NHT}$, yakni beberapa kelompok yang beranggotakan 3-5 orang siswa. Kemudian menomori serta memberi nama setiap kelompok. Usahakan masing-masing kelompok terdiri dari beragam karakter anak. Langkah 3. Tiap kelompok harus memiliki buku panduan Lengkapi setiap kelompok dengan buku panduan agar memudahkan mereka dalam mengerjakan tugas yang diberikan. Langkah 4. Memulai diskusi Memulailah memberikan tugas kepada siswa. Dan dalam kerja kelompok tersebut, pastikan semua siswa mengerti dengan pertanyaan serta jawaban yang hendak diberikan. Langkah 5. Memanggil nomor anggota Dalam tahap ini, guru menyebut satu nomor dan para siswa dari tiap kelompok dengan nomor yang sama mengangkat tangan dan menyiapkan jawaban kepada siswa dikelas. Langkah 6. Mengakhiri dengan kesimpulan Guru bersama siswa menyimpulkan jawaban akhir dari semua pertanyaan yang telah didiskusikan tadi. 
Ibrahim, (2000) mengemukakan tiga tujuan yang hendak dicapai dalam pembelajaran kooperatif dengan tipe NHT yaitu: 1) Hasil belajar akademik struktural Bertujuan untuk meningkatkan kinerja siswa dalam tugas-tugas akademik. 2) Pengakuan adanya keragaman Bertujuan agar siswa dapat menerima teman-temannya yang mempunyai berbagai latar belakang. 3) Pengembangan ketrampilan sosial Bertujuan untuk mengembangkan ketrampilan sosial siswa.

Menggunakan model pembelajaran kooperatif model Number Head Together (NHT) memiliki beberapa kelebihan, seperti yang diungkapkan oleh Kurniasih \& Sani, (2015) bahwa "model pembelajaran Number Head Together (NHT) memiliki beberapa kelebihan yaitu: 1) model ini menuntut siswa harus aktif semua, 2) dengan model pembelajaran ini juga, siswa dituntut untuk melakukan diskusi dengan sungguh-sungguh, 3) siswa yang pandai dapat mengajari siswa yang kurang pandai".

Dalam menggunakan model pembelajaran Number Head Together (NHT) terdapat beberapa kelemahan yang harus diwaspadai, hal ini dilakukan agar tidak terjadi hal-hal yang tidak diinginkan dalam pembelajaran, adapun kelemahan-kelemahan tersebut menurut Kurniasih \& Sani, (2015) adalah "1) tidak terlalu cocok untuk jumlah siswa yang banyak karena membutuhkan waktu yang lama, 2) karena keterbatasan waktu, mengakibatkan semua anggota kelompok tidak bisa mengutarakan pendapatnya".

Dimyati dan Moedjiono (2009) menyatakan bahwa "hasil belajar merupakan hasil dari suatu interaksi tindak belajar atau tindak mengajar". Hasil belajar dapat diartikan sebagai suatu tindakan atau suatu proses untuk menentukan nilai keberhasilan belajar seseorang setelah ia mengalami proses belajar selama satu periode tertentu (Nurkancana \& Sunartana, 1990). Susanto, (2003) menyatakan bahwa hasil belajar adalah kemampuan yang diperoleh anak setelah melalui kegiatan belajar.
Bloom (dalam Sudjana, 2010) membagi hasil belajar menjadi tiga kawasan yaitu kognitif, afektif, dan psikomotor. Kawasan kognitif berkenaan dengan ingatan atau pengetahuan dan kemampuan intelektual serta keterampilan-keterampilan. Kawasan afektif menggambarkan sikap, minat, dan nilai serta pengembangan pengertian atau pengetahuan dan penyesuaian diri yang memadai. Kawasan psikomotor adalah kemampuan-kemampuan menggiatkan dan mengkoordinasikan gerak.

Wahaya (dalam Trianto, 2010) mengatakan bahwa, "IPA adalah suatu kumpulan pengetahuan tersusun secara sistematik dan dalam penggunaannya secara umum terbatas pada gejalagejala alam. Perkembangannya tidak hanya ditandai oleh adanya kumpulan fakta, tetapi oleh adanya metode ilmiah dan sikap ilmiah". Trianto, (2011) menyimpulkan bahwa IPA adalah suatu kumpulan teori yang sistematis, penerapannya secara umum terbatas pada gejala-gejala alam, lahir dan berkembang melalui metode ilmiah seperti observasi dan eksperimen serta menuntut sikap ilmiah seperti rasa ingin tahu, terbuka, jujur dan sebagainya. Menurut Samatowa, (2010) ada berbagai alasan yang menyebabkan suatu mata pelajaran itu dimasukan ke dalam kurikulum suatu sekolah.

Faktor-faktor yang mempengaruhi hasil belajar yaitu faktor dari dalam diri individu yaitu bakat, minat, intelegensi, kematangan, kesehatan jasmani dan faktor luar individu meliputi fasilitas belajar, waktu, media belajar, cara guru mengajar dan memotivasi (Susanto, 2003). Sedangkan menurut (Purwanto, 2000) mengatakan yang mempengaruhi hasil belajar adalah (1) faktor guru yang dipengaruhi oleh pandangannya tentang mengajar, konsep, psikologi dan kurikulum, (2) faktor siswa yang meliputi kecakapan potensi maupun kecakapan yang diperoleh dari hasil belajar, (3) faktor kurikulum, (4) faktor lingkungan.

Dalam pembelajaran kooperatif tipe Number Head Together (NHT) siswa diharapkan dapat menerima pelajaran 
atau informasi dari guru, dan dari siswa lain juga dapat memberikan informasi pada siswa yang lainnya. Dalam model pembelajaran kooperatif tipe Number Head Together (NHT), siswa diharapkan dapat lebih aktif, sehingga kegiatan pembelajaran yang dihasilkan pun lebih interaktif, pengetahuan yang diperoleh siswa pun akan lebih lama diingat dan dipahami oleh siswa karena pengetahuan yang didapat dibangun sendiri oleh siswa pula. Pembelajaran ini dimaksudkan agar siswa dapat lebih aktif dalam interaksi yang diciptakan guru dalam proses pembelajaran. Aktif tidaknya siswa dalam mengikuti proses pembelajaran nantinya akan berpengaruh pada hasil belajar yang akan dicapai oleh siswa tersebut. Hal ini dikarenakan keaktifan siswa mempunyai peranan yang sangat penting dalam proses pembelajaran, tanpa adanya aktivitas siswa maka proses pembelajaran tidak akan berjalan dengan baik, dan hasil belajar yang dicapai pun akan rendah.

Dalam proses pelaksanaan pembelajaran Number Head Together (NHT) akan membantu untuk menyampaikan materi pembelajaran IPA sehingga siswa akan fokus pada proses pembelajaran dan dapat memahami materi yang diberikan, hal ini diharapkan akan dapat membantu siswa untuk memperoleh hasil belajar yang memuaskan. Maka dapat disimpulkan melalui penerapan model pembelajaran Number Head Together (NHT) diharapkan hasil belajar siswa meningkat.

Berdasarkan landasan teori dan kerangka berpikir di atas, dapat dirumuskan hipotesis tindakan sebagai berikut. "Jika model pembelajaran Number Head Together (NHT) diterapkan secara optimal, maka hasil belajar IPA pada siswa kelas III SD No. 2 Abianbase Tahun Pelajaran 2016/2017 dapat ditingkatkan".

\section{METODE}

Jenis penelitian yang dilaksanakan adalah penelitian tindakan kelas
(Classroom Action Research). Penelitian tindakan kelas ini memilki empat tahapan pada satu siklus penelitian. Keempat tahapan tersebut terdiri dari: perencanaan, tindakan, pengamatan, dan refleksi (Arikunto, 2009). Penelitian tindakan kelas ini dilaksanakan di SD No. 2 Abianbase, Kecamatan Mengwi Kabupaten Badung-Bali. Penelitian ini dilaksanakan pada Tahun Pelajaran 2016/2017. Penentuan waktu penelitian mengacu kepada kalender pendidikan SD No. 2 Abianbase.

Penelitian tindakan kelas ini dilaksanakan di SD No.2 Abianbase Kabupaten Badung dengan subjek penelitian adalah siswa kelas III Tahun Pelajaran 2016/2017, dengan jumlah siswa 31 orang yang terdapat 16 orang siswa laki-laki dan 15 orang siswa perempuan. Sedangkan objek penelitian ini adalah hasil belajar IPA siswa.

Adapun metode pengumpulan data yang digunakan dalam penelitian ini adalah metode tes. Data hasil belajar IPA dikumpulkan melalui tes tertulis objektif berbentuk pilihan ganda biasa dengan 4 options berjumlah 20 butir soal. Metode analisis data penelitian ini menggunakan metode deskriptif kuantitatif.

Skor masing-masing siswa dihitung dengan rumus:

$$
\text { Skor }=\frac{\text { Skor yang diperoleh }}{\text { Skor maksimal }} \times 100
$$

(1)

Rata-rata hasil belajar siswa dihitung dengan rumus:

$$
X=\frac{\sum x}{N}
$$

(2)

Persentase rata-rata hasil belajar dihitung dengan rumus:

$$
M \%=\left[\frac{M}{S M I}\right] X 100 \%
$$

Untuk mengetahui kategori hasil belajar siswa, persentase rata-rata hasil belajar yang telah diperoleh dengan menggunakan rumus dapat dikonversikan ke dalam tabel kategori 
penskoran acuan patokan (PAP) Agung (2005).

\begin{tabular}{cc} 
Tabel 1. Kategori Penilaian Acuan Patokan (PAP) \\
\hline Persentase Penguasaan & Kategori \\
\hline $90-100$ & Sangat tinggi \\
$80-89$ & Tinggi \\
$65-79$ & Sedang \\
$55-64$ & Rendah \\
$0-54$ & Sangat rendah \\
\hline
\end{tabular}

Adapun indikator keberhasilan penelitian ini adalah terjadi peningkatan rata-rata hasil belajar IPA siswa secara klasikal dari siklus I ke siklus berikutnya dan pada akhir penelitian persentase rata-rata hasil belajar IPA siswa berada dalam kategori tinggi (80-89).

\section{HASIL DAN PEMBAHASAN}

Penelitian tindakan kelas ini dilaksanakan di kelas III SD No. 2 Abianbase Tahun Pelajaran 2016/2017 dengan jumlah siswa 31 yang terdiri dari 16 orang siswa laki-laki dan 15 orang siswa perempuan. Pelaksanaan penelitian ini dilaksanakan dalam dua siklus. Pada setiap siklus, dilaksanakan dengan 4 kali pertemuan, 3 kali pertemuan untuk pelaksanaan kegiatan pembelajaran dan 1 kali pertemuan untuk pelaksanaan evaluasi hasil belajar IPA.

Data yang dikumpulkan pada penelitian ini adalah data hasil belajar IPA siswa kelas III SD No. 2 Abianbase setelah diterapkannya model pembelajaran kooperatif tipe Number Head Together (NHT). Data mengenai hasil belajar IPA siswa yang telah dikumpulkan kemudian dianalisis untuk mengetahui peningkatan rata-rata kelas hasil belajar IPA.

Pelaksanaan siklus I pada penelitian ini dilaksanakan dalam 4 kali pertemuan, 3 kali pertemuan untuk pelaksanaan kegiatan pembelajaran dan 1 kali pertemuan untuk pelaksanaan evaluasi hasil belajar IPA. Pertemuan pertama hari Selasa tanggal 25 Oktober
2016, pertemuan kedua hari Jumat tanggal 28 Oktober 2016, pertemuan ketiga dilaksanakan pada hari Selasa tanggal 01 November 2016 dan untuk evaluasi hasil belajar IPA dilaksanakan pada hari Jumat tanggal 04 November 2016 dengan menggunakan instrumen tes.

Berdasarkan hasil analisis data pada siklus I diperoleh rata-rata kelas hasil belajar IPA siswa kelas III SD No.2 Abianbase adalah 72,74 dengan persentase $\quad 72,74 \%$. Persentase dikonversikan ke dalam table 3.1 tentang kategori Peskoran Acuan Patokan (PAP) untuk mengetahui kategori hasil belajar IPA, ternyata persentase rata-rata hasil belajar IPA 72,74 \% termasuk kategori hasil belajar sedang (65-79). Dari data di atas menunjukkan hasil belajar IPA siswa belum mencapai kategori yang diharapkan. Oleh karena itu, dilaksanakan perbaikan pada siklus selanjutnya. Maka tindakan penelitian ini dilanjutkan ke siklus II.

Setelah

melaksanakan pembelajaran IPA dengan penerapan model pembelajaran kooperatif tipe Number Head Together (NHT) diperoleh beberapa catatan sebagai hasil observasi dalam pelaksanaan pembelajaran. Setelah dilakukan refleksi ternyata masih terdapat kendala-kendala yang harus diperbaiki pada siklus selanjutnya. Belum tercapainya kategori yang diharapkan disebabkan aktivitas siswa dalam bertanya ataupun menjawab pertanyaan masih kurang. Hanya beberapa siswa yang memiliki keberanian untuk bertanya atau 
menjawab. Siswa yang pintar sering kali mendominasi pada saat belajar dalam kelompok. Siswa belum bisa berbagai tugas, saling bertukar pendapat, dan bersama-sama mencari informasi untuk menyelesaikan tugas sehingga tugas tidak terselesaikan tepat waktu dan kelompok terkesan pasif. Guru telah berupaya memotivasi siswa agar siswa aktif mengemukakan pendapat, berdiskusi.

Berdasarkan refleksi siklus I selanjutnya pada siklus II dilakukan perbaikan atau penyempurnaan. Beberapa upaya yang dilakukan seperti merubah anggota kelompok belajar berdasarkan hasil tes siklus I. Hal ini dilakukan agar dalam satu kelompok terdiri dari siswa yang memiliki kemampuan merata. Membimbing siswa melatih keterampilan-keterampilan kooperatif saat melakukan diskusi dalam kelompok seperti saling berbagi tugas dan saling membantu antara anggota kelompok untuk memahami materi sehingga terjadi interaksi yang positif dan tidak ada yang diam atau pasif.

Memberikan pujian dan penguatan juga dilakukan untuk menumbuhkan keberanian dan rasa percaya diri siswa untuk bertanya ataupun menjawab yang berkaitan dengan pembelajaran. Penguatan mempunyai peranan yang sangat penting dalam meningkatkan keefektifan kegiatan pembelajaran.

Pelaksanaan siklus II pada penelitian ini dilaksanakan dalam 4 kali pertemuan, 3 kali pertemuan untuk pelaksanaan kegiatan pembelajaran dan 1 kali pertemuan untuk pelaksanaan evaluasi hasil belajar matematika. Pertemuan pertama hari Selasa tanggal 08 November 2016, pertemuan kedua dilaksanakan hari Jumat tanggal 11 November 2016, pertemuan ketiga dilaksanakan pada hari Selasa tanggal 15 Nopember 2016 dan untuk evaluasi hasil belajar IPA dilaksanakan pada hari Jumat tanggal 18 Nopember 2016 dengan menggunakan instrumen tes.

Berdasarkan hasil analisis data pada siklus II diperoleh rata-rata hasil belajar IPA siswa kelas III SD No. 2 Abianbase mencapai 81,93 dengan persentase $\quad 81,93 \%$. Persentase dikonversikan ke dalam tabel 3.1 tentang Kategori Peskoran Acuan Patokan (PAP) untuk mengetahui kategori hasil belajar IPA, ternyata persentase rata-rata hasil belajar IPA sebesar $81,93 \%$ termasuk kategori hasil belajar tinggi (80-89). Dilihat dari tindakan siklus II menunjukkan telah terjadi peningkatan hasil belajar IPA siswa sesuai dengan indikator keberhasilan yaitu terjadinya peningkatan rata-rata hasil belajar IPA siswa secara klasikal dari siklus I ke siklus II sebesar 9,19 dan perolehan persentase hasil belajar IPA siswa pada siklus II mencapai 81,93 \% berada pada kategori tinggi. Maka dari itu, penelitian ini sudah dikatakan berhasil sehingga siklus II dapat dihentikan.

Untuk memudahkan dalam mengetahui peningkatan data tentang hasil belajar siswa terhadap mata pelajaran IPA pada siklus I dan siklus II, maka dibuatlah ringkasan hasil penelitian sebagai berikut.

Tabel 2. Ringkasan Hasil Penelitian tentang Hasil Belajar IPA Siswa pada Siklus I dan Siklus II

\begin{tabular}{cccc}
\hline Tahapan & $\begin{array}{c}\text { Rata-Rata Hasil } \\
\text { Belajar }\end{array}$ & $\begin{array}{c}\text { Persentase } \\
\text { Hasil Belajar }\end{array}$ & Kategori \\
\hline Siklus I & 72,74 & $72,74 \%$ & Sedang \\
Siklus II & 81,93 & $81,93 \%$ & Tinggi \\
\hline
\end{tabular}

Berdasarkan penelitian yang telah dilaksanakan dalam dua siklus yang setiap siklus terdiri dari empat kali pertemuan yakni tiga kali pertemuan tatap muka dan satu kali pengadaan tes hasil belajar terjadi peningkatan hasil belajar siswa kelas III SD No. 2 Abianbase pada pelajaran IPA. Berdasarkan hasil yang diperoleh pada siklus I, rata-rata hasil belajar siswa 
pada siklus I hanya mencapai 72,74 dengan persentase sebesar $72,74 \%$ termasuk kategori hasil belajar sedang.

Belum tercapainya kategori yang diharapkan disebabkan aktivitas siswa dalam bertanya ataupun menjawab pertanyaan masih kurang. Hanya beberapa siswa yang memiliki keberanian untuk bertanya atau menjawab. Siswa yang pintar sering kali mendominasi pada saat belajar dalam kelompok. Siswa belum bisa berbagai tugas, saling bertukar pendapat, dan bersama-sama mencari informasi untuk menyelesaikan tugas sehingga tugas tidak terselesaikan tepat waktu dan kelompok terkesan pasif. Guru telah berupaya memotivasi siswa agar siswa aktif mengemukakan pendapat, berdiskusi. Yamin (2007) menyatakan “ keaktifan siswa dalam proses pembelajaran dapat merangsang dan mengembangkan bakat yang dimilikinya, berpikir kritis dan dapat memecahkan masalah dalam kehidupan sehari- hari". Dalam hal ini keaktifan siswa dalam proses pembelajaran adalah suatu kegiatan yang dilakukan siswa yang terlibat secara aktif dalam mengemukakan ide, bertanya, menyampaikan pendapat selama proses pembelajaran dalam menemukan suatu konsep. Kendalakendala yang dialami pada siklus I menjadi hambatan bagi siswa dalam mengikuti proses pembelajaran di kelas, sehingga pada siklus I belum mencapai target yang ditetapkan.

Berdasarkan refleksi siklus I selanjutnya pada siklus II dilakukan perbaikan atau penyempurnaan. Beberapa upaya yang dilakukan seperti merubah anggota kelompok belajar berdasarkan hasil tes siklus I. Hal ini dilakukan agar dalam satu kelompok terdiri dari siswa yang memiliki kemampuan merata. Membimbing siswa melatih keterampilan-keterampilan kooperatif saat melakukan diskusi dalam kelompok seperti saling berbagi tugas dan saling membantu antara anggota kelompok untuk memahami materi sehingga terjadi interaksi yang positif dan tidak ada yang diam atau pasif.

Berdasarkan hasil analisis data pada siklus II maka diperoleh rata-rata hasil belajar siswa mencapai 81,93 dan persentase nilai rata-rata siswa sudah mencapai $81,93 \%$ berada dalam kategori tinggi dengan tingkat rentang ketuntasan berada pada rentang skor 80-89.

Dari analisis data pada siklus I dan siklus II di atas, diketahui bahwa hasil belajar IPA meningkat melalui model pembelajaran kooperatif tipe Number Head Together (NHT) pada siswa kelas III SD No. 2 Abianbase semester ganjil tahun pelajaran $2016 / 2017$. Hal ini dapat dilihat dari ratarata hasil belajar siswa secara klasikal pada siklus I sebesar 72,74 dengan persentase rata-rata $72,74 \%$ yang tergolong pada kategori sedang. Pada siklus II rata-rata meningkat menjadi 81,93 dengan persentase rata-rata sebesar $81,93 \%$ yang berada dalam kategori tinggi. Seiring dengan peningkatan rata-rata hasil belajar siswa persentase rata-rata pun ikut meningkat. Peningkatan persentase rata-rata dari siklus I ke siklus II sebesar 9,19\%.

Terjadinya peningkatan hasil belajar siswa kelas III semester ganjil pada mata pelajaran IPA disebabkan oleh pada pelaksanaan tindakan siklus II tidak lagi muncul kendala-kendala pada siklus I. Beberapa upaya yang dilakukan pada siklus II seperti merubah anggota kelompok belajar berdasarkan hasil tes siklus I. Hal ini dilakukan agar dalam satu kelompok terdiri dari siswa yang memiliki kemampuan merata. Membimbing siswa melatih keterampilan-keterampilan kooperatif saat melakukan diskusi dalam kelompok seperti saling berbagi tugas dan saling membantu antara anggota kelompok untuk memahami materi sehingga terjadi interaksi yang positif dan tidak ada yang diam atau pasif.

$$
\text { Memberikan pujian dan }
$$

penguatan juga dilakukan untuk menumbuhkan keberanian dan rasa percaya diri siswa untuk bertanya ataupun menjawab yang berkaitan dengan pembelajaran. Penguatan 
mempunyai peranan yang sangat penting dalam meningkatkan keefektifan kegiatan pembelajaran. Menurut Sri Anitah (2014) Penguatan adalah respon yang diberikan terhadap perilaku atau perbuatan yang dianggap baik, yang dapat membuat terulangnya atau meningkatnya perilaku/perbuatan yang dianggap baik tersebut. Menyampaikan pada siswa bahwa setiap aktivitas belajar yang dilakukan disertai penilaian dengan harapan siswa termotivasi untuk melaksanakan pembelajaran. Selain itu dilakukan pendekatan secara pribadi pada siswa yang mengalami kesulitan dalam pembelajaran. Upaya perbaikan yang dilakukan telah membuahkan hasil yang baik. Terlihat dari ketepatan waktu siswa mengerjakan tugas yang diberikan, sehingga masing-masing kelompok dapat menyampaikan hasil kerja kelompoknya dengan baik.

dalam Adanya refleksi membantu pembelajaran pada siklus II. Siswa sudah nampak aktif saat belajar dalam kelompok karena siswa sudah mau bekerja sama dalam menyelesaikan masalah. Dengan bekerja sama dapat menyelesaikan pekerjaan dengan cepat. Menurut Zaltman et.al (1972) mengemukakan siswa yang sama-sama bekerja dalam kelompok akan menimbulkan persahabatan yang akrab, yang terbentuk di kalangan siswa, ternyata sangat berpengaruh pada tingkah laku atau kegiatan masingmasing secara individual. Siswa sangat antusias dalam belajar dan sebagian mau bertanya serta mengeluarkan pendapat sehingga tugas terselesaikan tepat waktu. Peningkatan keaktifan dan hasil belajar siswa sangat didukung oleh kondisi belajar siswa.

Untuk mencapai hasil belajar IPA yang optimal, salah satu faktor yang menentukan adalah keterlibatan aktif siswa dalam proses pembelajaran. Siswa diberikan kesempatan untuk mengalami dan menemukan sendiri pemecahan masalah yang dihadapi sehingga apa yang dipelajari akan bertahan lama dalam ingatan. Peran guru tidak lagi menjadi pusat pembelajaran. Menurut
Lapono, dkk. (2008) aktivitas peserta didik menjadi syarat utama dalam pembelajaran konstruktivisme. Peranan guru hanya sebagai fasilitator atau pencipta kondisi belajar yang memungkinkan peserta didik secara aktif mencari sendiri informasi, mengasimilasi dan mengadaptasi sendiri informasi, dan mengkonstruksinya menjadi pengetahuan yang baru berdasarkan pengetahuan yang telah dimiliki masingmasing.

Melihat peningkatan hasil belajar siswa dalam pembelajaran IPA yang menerapkan metode pembelajaran pemberian tugas, dapat diketahui bahwa metode pemberian tugas ini sangat memberikan sumbangan positif dalam proses pembelajaran dan hasil belajar siswa yang optimal serta sangat baik digunakan dalam peningkatan kualitas pembelajaran sekolah dasar. Pembelajaran pemberian tugas dapat memudahkan siswa melakukan penyesuaian sosial, mengembangkan kegembiraan belajar yang sejati, memungkinkan siswa saling belajar mengenai sikap, keterampilan, informasi, perilaku, sosial dan pandangan.

Dari uraian di atas, secara umum telah mampu menjawab rumusan masalah. Penelitian ini dapat dikatakan berhasil, karena semua kriteria yang ditetapkan telah terpenuhi. Jadi, dapat dinyatakan bahwa penerapan model pembelajaran Kooperatif tipe Numbered Head Together (NHT) dapat meningkatkan hasil belajar IPA siswa kelas III SD No. 2 Abianbase tahun pelajaran 2016/2017.

\section{SIMPULAN DAN SARAN}

Dari hasil dan pembahasan penelitian maka dapat disimpulkan sebagai berikut. Terjadinya peningkatan hasil belajar siswa dalam mata pelajaran IPA melalui penerapan model pembelajaran (Number Head Together) NHT pada siswa kelas III SD No. 2 Abianbase. Hal ini terbukti dari peningkatan rata-rata hasil belajar, persentase rata-rata hasil belajar, pada siklus I diperoleh nilai rata-rata hasil belajar 72,74, persentase hasil belajar 
$72,74 \%$ berada pada kategori "sedang". Sedangkan pada siklus II hasil belajar meningkat yaitu nilai rata-rata hasil belajar siswa mencapai 81,93 persentase rata-rata $81,93 \%$ berada dalam kategori "tinggi".

Sesuai dengan hasil penelitian tindakan kelas maka, disarankan agar guru IPA khususnya di sekolah dasar dapat menerapkan pembelajaran dengan menggunakan model NHT (Number Head Together) sebagai salah satu alternatif dalam melaksanakan pembelajaran yang inovatif. Media-media yang dikorelasikan dengan kondisi nyata, yang ada pada lingkungan sekitar siswa. Dengan demikian kegiatan yang dilakukan oleh siswa memberikan nilai yang bermakna pada pemahaman siswa mengenai materi yang dipelajari dalam upaya meningkatkan hasil belajar IPA. Perlunya model pembelajaran NHT (Number Head Together) ini diterapkan pada kelas yang lain atau mata pelajaran lain sehingga dapat memperkaya model pembelajaran yang selama ini digunakan.

Siswa kelas III SD No 2 Abianbase hendaknya lebih memerhatikan dan memahami materi yang diberikan oleh guru dalam proses pembelajaran melalui pengembangan karakter bangsa agar dapat menambah wawasan pengetahuan siswa.

Peneliti diharapkan dapat menambah wawasan dengan mengunakan metode yang lebih kreatif dan dapat mengkondisikan kelas.

\section{DAFTAR PUSTAKA}

Agung, A.A Gede. 2005. Metodologi Penelitian Pendidikan. Singaraja : UNDIKSHA.

Agustin, Setya \& Aryanto, Sugeng. Antara, Sukma. 2013. The Effect Of Using Numbered Head Together Technique On The Eighth Grade Students' Reading Comprehension Achievement At Smpn 2 Tanggul Jember Jurnal Pancaran. 2 (3). 201-210.

Arikunto, dkk.2009. Penelitian Tindakan Kelas. Jakarta : PT Bumi Aksara.
Dimyati dan Moedjiono. 2009. Belajar dan Pembelajaran. Jakarta: Rineka Cipta

Ibrahim, M. 2000. Pembelajaran Kooperatif. University Press. Surabaya.

Kurniasih \& Sani. 2015. Model Pembelajaran. Jakarta : Kata Pena

Kusumaningtyas, Y. P., \& Kusmayadi, T. A. (2014). Eksperimentasi Model Pembelajaran Think Talk Write ( Ttw ) Dan Numbered Head Together ( Nht ) Terhadap Prestasi Belajar Matematika Ditinjau Dari Konsep Diri Belajar Matematika Siswa Di Smp Negeri E-Kabupaten Blora. Jurnal Elektronik Pembelajaran Matematika 2(2), 215-225.

Lapono, Nabisi, dkk. 2008. Belajar dan Pembelajaran SD. Jakarta: Direktorat Jenderal Pendidikan Tinggi Departemen Pendidikan Nasional.

Miaz, Y. (2015). The Implementation Of Numbered Heads Together To Improve The Students' Achievement Of Social Sciences In Primary School. Research Journal of Social Sciences. 8 (10). 40-45.

Nur, Mohamad. 2005. Pembelajaran Kooperatif. Jawa Timur: Depdiknas.

Nurkancana dan Sunartana. 1990. Evaluasi Hasil Belajar. Surabaya : Usaha Nasional.

Purwanto, M. Ngalim. 2000. Psikologi Pendidikan. Bandung : Remaja Rosdakarya.

Puspa, D., Danti, N., Suprayitno, I. J., Prihaswati, M., Konstruktivisme, P., \& Belajar, P. (2015). Perbandingan Pembelajaran Number Head Together Dengan Team Assisted Individualization Berpendekatan, 2(April). JKPM. 2 (1). 15-21. 
Sudjana, Nana. 2010. Penilaian Hasil Proses Belajar Mengajar. Bandung : Sinar Biru

Susanto, A.B. 2003. "Mengembangkan Corporate Social Responsibility di Indonesia", JurnalReformasiEkonomi,Volume No. 1 Hal 8, Jakarta

Trianto. 2007, Model Pembelajaran Terpadu dalam Teori dan Praktek, Jakarta: Prestasi Pustaka.

-----. 2010. Model Pembelajaran Terpadu. Jakarta: PT. Bumi Aksara.

-----, 2011, Model Pembelajaran Terpadu Konsep,Strategi Dan Implementasinya Dalam Kurikulum Tingkat Satuan Pendidikan (KTSP), Jakarta : Bumi Aksara

Samatowa, Usman. 2011. Pembelajaran IPA Di Sekolah Dasar. Jakarta : Indeks

Shoimin, Aris. 2014. 68 Model Pembelajaran Inovatif dalam Kurikulum 2013. Yogyakarta: ArRuzz Media.

Sri Anitah W. dkk. 2014. Strategi Pembelajaran di SD. Tangerang. Universitas Terbuka.

Suprijono, Agus. 2009. Cooperative Learning Teori \& Aplikasi Paikem. Surabaya: Pustaka Pelajar.

Yamin, Martinis. 2007. Strategi Pembelajaran Berbasis Kompetensi. Jakarta: Gaung Persada Press.

Zaltman Gerald et al, 1972, Creating Social Change, New York ; Holt, Rinehart and Winston, Inc. 